\title{
PENERAPAN SISTEM KEGIATAN BELAJAR DAN MENGAJAR DALAM INSTRUMEN SERTIFIKASI DOSEN PROFESIONAL MENGGUNAKAN METODE SMART
}

\author{
Verdi Yasin \\ Departemen Teknik Informatika, STMIK Jayakarta \\ Koresponden Email: verdiyasin29@gmail.com
}

\begin{abstract}
Abstrak: Penerapan system kegiatan belajar dan mengajar (KBM) perlu mengikuti perkembangan teknologi informasi dan sistem digital berbasis multimedia. Kebutuhan model belajar dan mengajar yang inovasi, maka perlu ada suatu metode yang tepat guna, sedangkan konsep metode belajar dan mengajar harus mengikut kebutuhan pasar dan standar kelayakan kompetensi seorang dosen. Maka untuk itu Pemakalah/Pemateri (Narasumber) menganalisis suatu metode yang tepat guna yakni Metode SMART. Metode SMART Merupakan akronim dari S=Simple, M=Modern-more innovative, A=Accountable, $\boldsymbol{R}=$ Responsive, $\boldsymbol{T}=$ Transparent . Prinsipel proses kegiatan belajar dan mengajar menggunakan metode SMART ialah semua kegiatan belajar dan mengajar, penelitian dan publikasi, serta pengabdian masyarakat yang laksanakan oleh dosen sebagai wujud Tri Dharma Perguruan Tinggi, harus memilki bukti rekam jejak pada sistem informasi dan sistem digital dan multimedia, berupa Link Publikasi, Foto Acara, Rekaman Audio dan Video, dan semuanya transparan dan bertanggungjawab setiap momen kegiatan dan dilengkapi dengan dokumentasi digital.
\end{abstract}

Kata Kunci: Kegiatan Belajar dan Mengajar, Metode SMART, Dokumentasi Digital.

Abstract: The application of learning and teaching system (KBM) needs to follow the development of information technology and multimedia-based digital system. The need for an innovative learning and teaching model, there needs to be an appropriate method, while the concept of learning and teaching methods must follow the needs of the market and the standard of competency feasibility of a lecturer. Therefore, Pemakalah / Speaker (Speaker) analyzes an appropriate method that is SMART Method. SMART Method Is an acronym of S=Simple, M=Modern-more innovative, A=Accountable, $\boldsymbol{R}=$ Responsive, $\boldsymbol{T}=$ Transparent . The principal of the process of learning and teaching activities using smart method is all learning and teaching activities, research and publication, as well as community service carried out by lecturers as a form of Tri Dharma Higher Education, must have evidence of track record on information systems and digital and multimedia systems, in the form of Publication Links, Event Photos, Audio and Video Recordings, and all are transparent and responsible for every moment of activity and equipped with digital documentation.

This work is licensed under a Creative Commons Attribution-NonCommercial-ShareAlike 4.0 International License. 
Keywords: Learning and Teaching Activities, SMART Methods, Digital Documentation.

\section{PENDAHULUAN (Introduction)}

Penerapan sistem pelaksanaan perkuliahan yakni mengenai kegiatan belajar dan mengajar mengalami perubahan zaman, sesuai perkembangan teknologi dunia, makan syarat ketentuan standar intrumen dekripsi diri calon sertifikasi dosen, sehingga harapan pemerintah bahwa dengan adaanya sertifikasi dosen professional dapat meningkatkan kompetensi kemampuan mengampuh/kemampuan dosen dalam mendidik mahasiswa/mahasiswa dapat lebih baik. Selain itu dosen dituntut untuk menjalankan Tri Dharma Perguruan Tinggi pada bidang ilmu yang ajarkannya dapat dikembangkan melalui penelitian dan publikasi serta memberi pelatihan kepada masyarakat atau mahasaiswa/mahasiswi yang diampuhnya.

Perubahan system belajar dan mengajar di masa atau era revolusi industry 4,0 ini, teknologi informasi sebagai tools yang terdepan untuk digunakan oleh seorang dosen dalam melakukan/melaksanakan proses belajar dan mengajar dengan melalui kuliah daring, sehingga tidak ada alasan oleh seorang dosen profesioanl untuk tidak maksimal dalam melaksanakan tugasnya sebagai dosen pengampuh matakuliah, penelitian serta pengabdian masyaratkan. Semua itu dapat dilaksanakan melalui teknologi informasi dan teknologi digital, Video, audio dan sistem multimedia lainnya.

Ada beberapa elemen komponen instrument utama dalam melaksanakan tugas dosen profesioan ialah Dosen harus paham tentang tugas dan tanggung jawab nya sebagai professional bidang ilmiah, karena dosen adalah Ilmuwan/Ilmuwati yang memiliki kemampuan analisis lebih tinggi. Instrumen Penting yang harus diperhatikan oleh dosen professional ialah : Ilmu Pedagogik, Kemampuan Analisis dan Penelitian, serta Kemampuan dalam Pelayanan dan Pengabdian Kepada Masyarakat, sebagai Wujut nyata pengembangan pengetahuan dari hasil penelitian atau pemikiran dari seorang dosen.

Sedangkan syarat dan ketentuan Lulus dalam mengikut Sertifikasi seorang dosen professional ialah harus memenuhi unsur utama instrument sertifikasi dosen dibawah ini yakni ada 3 Unsur Utama dalam Instrumen Penilaian LULUS Sertifikasi dosen sebagai berikut:
A. Unsur A. Pendidikan dan Pengajaran
B. Unsur B. Penelitian dan Publikasi Ilmiah
C. Unsur C. Pengabdian Kepada Masyarakat 
TRIDHARMADIMAS: Jurnal Pengabdian Kepada Masyarakat Jayakarta

http://journal.stmikjayakarta.ac.id/index.php/tridharmadimas

EmaiL: info@stmik.jayakarta.ac.id , tridharmadimas.jayakarta@gmail.com

E-ISSN: 2798-8295 (Online), P-ISSN: 2798-8554 (Print) Vol. 1 No.1, Juli 2021

DOI : https://doi.org/10.52362/tridharmadimas.v1i1.501 Halaman 37-55

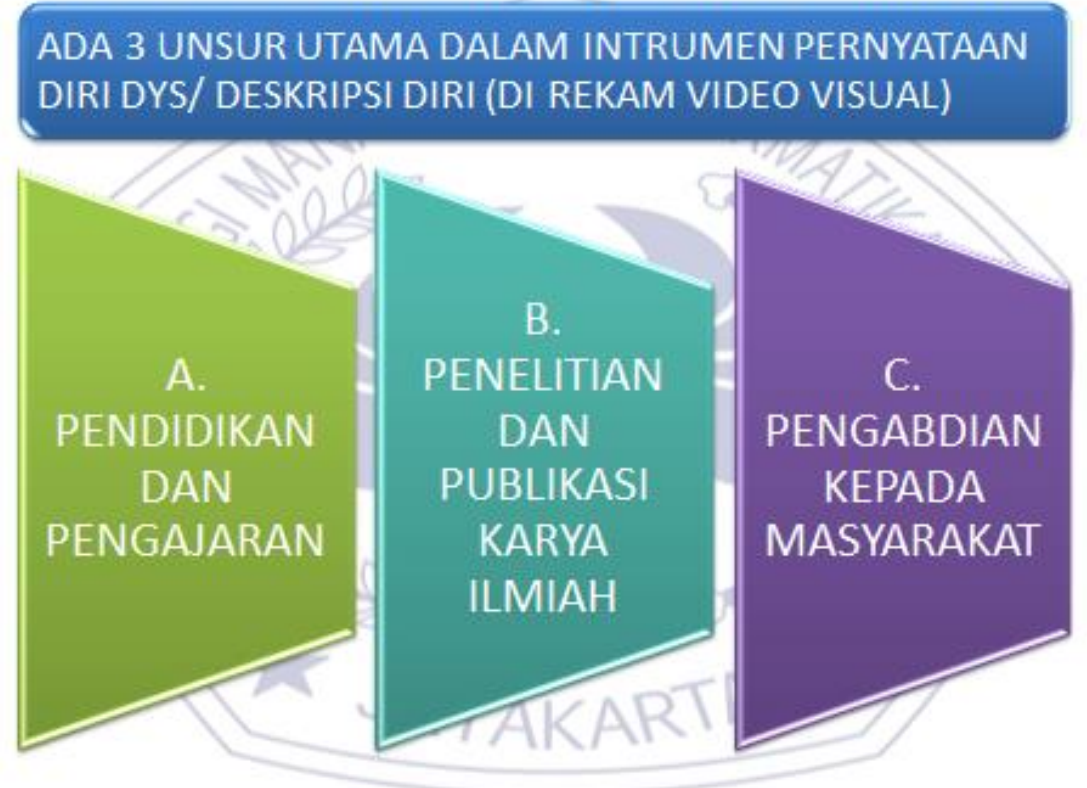

Gambar 1. Unsur Utama dalam Instrumen Sertifikasi Dosen untuk Pernyataan Diri/Deskripsi Diri.

Dalam menjelaskan konten dari tiga unsur diatas, harus ada relevansi antar bidang ilmu yang diampuh dengan pelaksanaan ketiga unsur yang dimaksud diatas dan dapat dijelaskan secara lengkap dalam pernyataan diri atau deskripsi diri dari seorang dosen, sedangkan pernyataan diri atau deskripsi diri seorang dosen, harus mengacu pada proses menjalankan Tri Dharma Perguruan Tinggi juga mengacu pada Riwayat Mengajar, Penelitian dan Pengabdian kepada masyarakat.

Maka dalam hal ini Narasumber/Pemateri, mengusulkan suatu metode baru yang dapat sebagai acuan standar kegiatan belajar dan mengajar (KBM), yakni menggunakan Metode SMART. Ini sangat tepat untuk digunakan sebagai tolok ukur pencapaian kompetensi dosen profesional.

Penjelasan lebih lengkap tentang Metode SMART, dapat dilihat pada bagian Metode dari Naskah Makalah Pengabdian Kepada Masyarakat.

\section{METODE}

Metode merupakan suatu cara yang digunakan dalam menyelesaikan masalah yang akan dikerjakan oleh seorang peneliti atau pemakalah (Narasumber). Maka untuk Pemakalah (Narasumber) menemukan suatu solusi berupa Metode yang dapat digunakan melaksanakan Tri Dharma Perguruan Tinggi agar dapat

This work is licensed under a Creative Commons Attribution-NonCommercial-ShareAlike 4.0 International License. 
TRIDHARMADIMAS: Jurnal Pengabdian Kepada Masyarakat Jayakarta

http://journal.stmikjayakarta.ac.id/index.php/tridharmadimas

EmaiL: info@stmik.jayakarta.ac.id , tridharmadimas.jayakarta@gmail.com

E-ISSN: 2798-8295 (Online), P-ISSN: 2798-8554 (Print) Vol. 1 No.1, Juli 2021

DOI : https://doi.org/10.52362/tridharmadimas.v1i1.501 Halaman 37-55

menjadi dosen Profesional dan bertanggungjawab terhadap tugas yang ditugaskan kepadanya, Medode yang Narasumber/Pemakalah Temukan dan Telah di Seminar pada acara Webinar Seminar Nasional dengan Tema: Strategi Lulus Sertifikasi Dosen, diselenggaran oleh Sekolah Tinggi Manajemen Informatika dan Komputer (STMIK Jayakarta) pada hari Sabtu tanggal 10 April 2021. Metode yang disampaikan oleh Narasumber/Pemateri (Verdi Yasin) ialah Metode SMART.

Filosofi Metode SMART merupakan akronim dari ; Simple, Modern-more Innovatif, Accountable, Responsive, Transparent (oleh; Verdi Yasin). Dibawah ini Siklus Hidup SMART ( SMART Life Cycle).

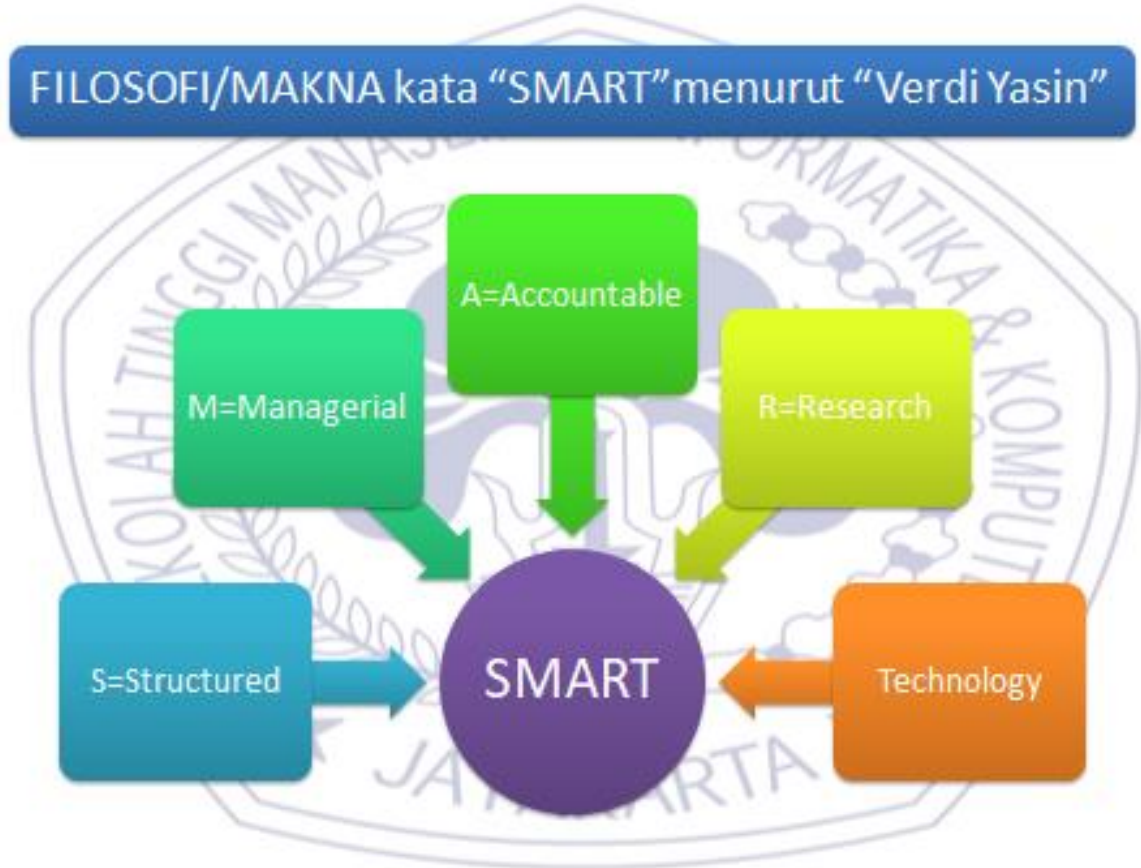

Gambar 2. Siklus Hidup Metode SMART (Sumber: Verdi Yasin, Sabtu, 10 April 2021)

Untuk memahami tentang Metode SMART, maka Pemakalah (Narasumber) menjelaskan sebagai berikut:

- $S=$ Simple ialah Dosen Profesional menyampaikan penjelasan atas materi kuliah yang diampuhnya, mudah dipahami, mudah dianalisis, mudah dikembangkan, mudah diterapkan dan tidak ambigu, relevan dengan matakuliah yang diampuhnya saat sekarang.

- M=Modern-more innovative ialah Dosen Profesional, senantiasa memberikan dan mengembangkan materi kuliah pengampunya sesuai kebutuhan masyarakat dan sesuai

This work is licensed under a Creative Commons Attribution-NonCommercial-ShareAlike 4.0 International License. 
perkembangan teknologi, dalam materi harus menyampaikan beberapa contoh/penjabaran pokok bahasan yang akan disampaikan kepada Mahasiswa/Mahasiswi atau Audiens/Peserta hadir.

- A=Accountable ialah Dosen Profesional, bertanggungjawab atas Tugasnya sebagai Akademisi, senantiasa memperhatikan Kompetensi Keilmuan, serta memberi kontibusi Ilmu yang terhadap perguruan tinggi serta memberi manfaat terhadap mahasiswa.mahasiswi yang diampuh, dan membangun karakter berbeda, dan hasil yang mendukung keberhasilan kampus dan mahasaiswa/mahasiswi yang mengikuti matakuliah yang diampuh oleh dosen yang bersangkutan.

- $\boldsymbol{R}=$ Responsive ialah Dosen Profesional, senantiasa menggapi semua pertanyaan atau kritikan yang disampaikan oleh audiens/ mahasiswa/mahasiswi, dengan memberikan penjelasan atau tanggapan yang dapat dipahami atau dimengerti oleh penanya atau pengkritik, sehingga tidak menimbulkan adanya potensi asumsi kritikan atau penilaian tidak baik, tidak kompeten dan persepsi negatif terhadap dosen yang bersangkutan.

- $\quad \boldsymbol{T}=$ Transparent ialah Dosen Profesional, menyampaikan materi kuliah secara terbuka, agar tidak menimbulkan kontroversi dalam memahami pokok bahasan yang disampaikan. Sehingga tidak menimbulkan Penfsiran yang tidak relevan dengan bidang ilmu yang diampuh. Selanjutnya semua proses belajar dan mengajar, dibuat rekam proses kegiatan menggunakan fasilitas tools teknologi dan multimedia seperti Komputer, Mobile, Smarphone, Audio, Video, Camera, Tape dan lain-lain yang dapat digunakan sebagai bukti pelaksanaan Pendidikan, Penelitian dan Pengabdian Kepada Masyarakat.

Sehingga dapat disimpulkan, bahwa Metode SMART sangat tepat untuk diterapkan dengan perkembangan sistem belajar dan mengajar berbasis Teknologi Informasi dan Sistem Digital serta Multimedia.

\section{PEMBAHASAN}

Tujuan Sertifikasi dosen ialah untuk melahirkan dosen professional dan memiliki kompetensi dan melahirkan output dan Outcome dari matakuliah yang diampuhnya. Dibawah ini gambaran pencapaian seorang dosen professional yang akan disertifkasikan. 


\section{TUJUAN SERTIFIKASI DOSEN}

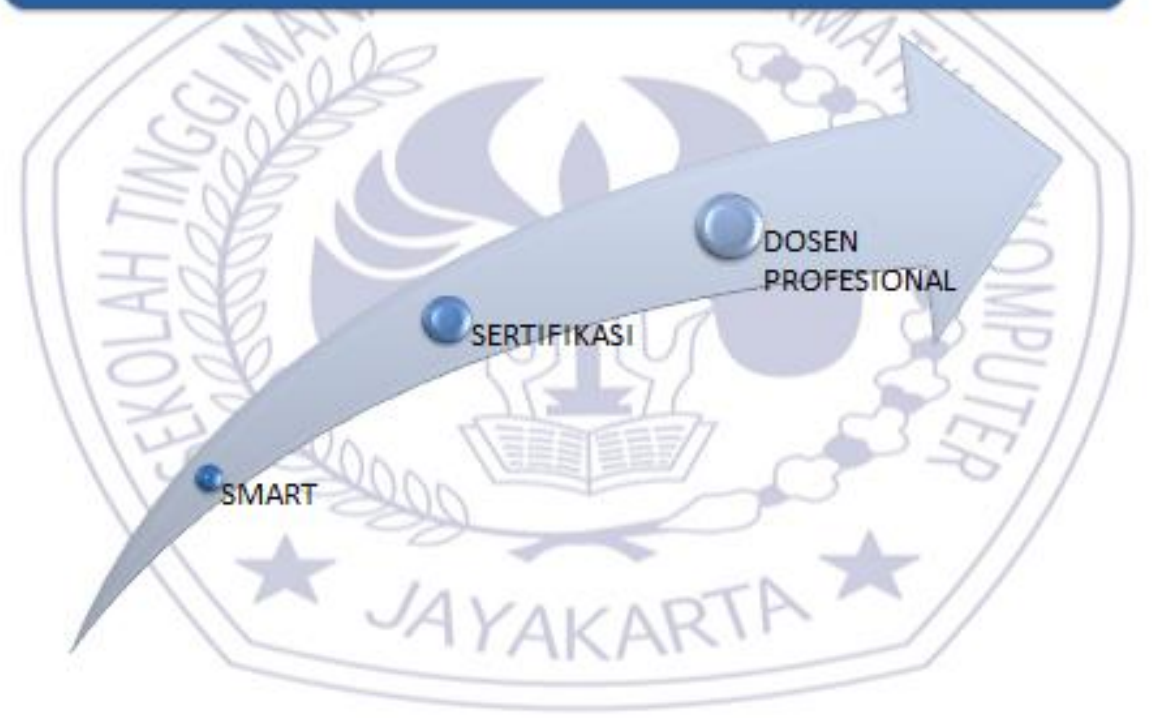

Gambar 3. Siklus Hidup Tujuan Sertifikasi Dosen (Sumber: Verdi Yasin, Sabtu 10 April 2021)

Gambar 3. Merupakan model prose pencapaian seorang dosen yang menjalankan Tri Dharma Perguruan Tinggi. Untuk lebih jelas, maka Pemakalah (Narasumber) menjabarkan sebagai berikut:

$\checkmark$ SMART Merupakan Metode yang dapat gunakan untuk melaksanakan Unsur Utama dalam mengikut Sertifikasi Dosen Yakni seorang dosen ; S=Simple, M=Modern-more innovative, A=Accountable, $R=$ Responsive, $T=$ Transparent

$\checkmark$ Sertifikasi ialah suatu standar yang diselenggarakan oleh pemerintah dalam hal ini Direktorat Jenderal Pendidikan Tinggi (DIKTI), untuk mendapatkan dan memberikan pengakuan terhadap dosen yang memenuhi syarat Dosen Sertifikasi melalui Proses Tes TKDA (Tes Kemampuan Dasar Akademik), Tes TKBI (Tes Kemampuan Bahasa Inggris), Mengisi Riwayat Hidup dan Identitas Pribadi, Riwayat Mengajar, Riwayat Penelitian dan Publikasi Ilmiah, Riwayat Pengabdian Kepada Masyarakat dan Riwayat Mengikuti Pertemuan Ilmiah, dan semua itu harus memiliki Rekam Jejak, dalam bentuk Video (Tersimpan di Youtube) atau penyimpanan yang ) dan Publikasi. Selanjutnya Mengisi Pernyataan Diri dengan Instrumen Unsur Pernyataan diri tentang "Pendidikan dan Pengajaran, Penelitian dan Publikasi, Pengabdian kepada Masyarkata serta karya buku Referensi, Buku Monograf atau Buku Ajar. 
TRIDHARMADIMAS: Jurnal Pengabdian Kepada Masyarakat Jayakarta

http://journal.stmikjayakarta.ac.id/index.php/tridharmadimas

EmaiL: info@stmik.jayakarta.ac.id , tridharmadimas.jayakarta@gmail.com

E-ISSN: 2798-8295 (Online), P-ISSN: 2798-8554 (Print) Vol. 1 No.1, Juli 2021

DOI : https://doi.org/10.52362/tridharmadimas.v1i1.501 Halaman 37-55

$\checkmark$ Dosen Profesional yaitu Dosen yang telah mendapatkan pengakuan dari DIKTI dan Telah melaksanakan Proses Sertifikasi dan Mendapatkan Srtifikat Doses (SERDOS), selanjut Dosen yang sudah sertifikasi, akan mendapatkan Tunjangan Sertifikasi Dosen setiap bulanya, dengan menyesuai Golongan melalui Inpasing Gologan dan Pangkat. Setelah Dosen yang bersamgkutan maka mulai melaksanakan Tri Dharma Perguruang Tinggi dengan maksimal, sesuai bidang ilmu pengampunya.

Penjelas lebih lengkap tentang Unsur Utama dalam Instrumen Sertifikasi Dosen Ialah :

\section{A. Unsur A. Pendidikan dan Pengajaran}

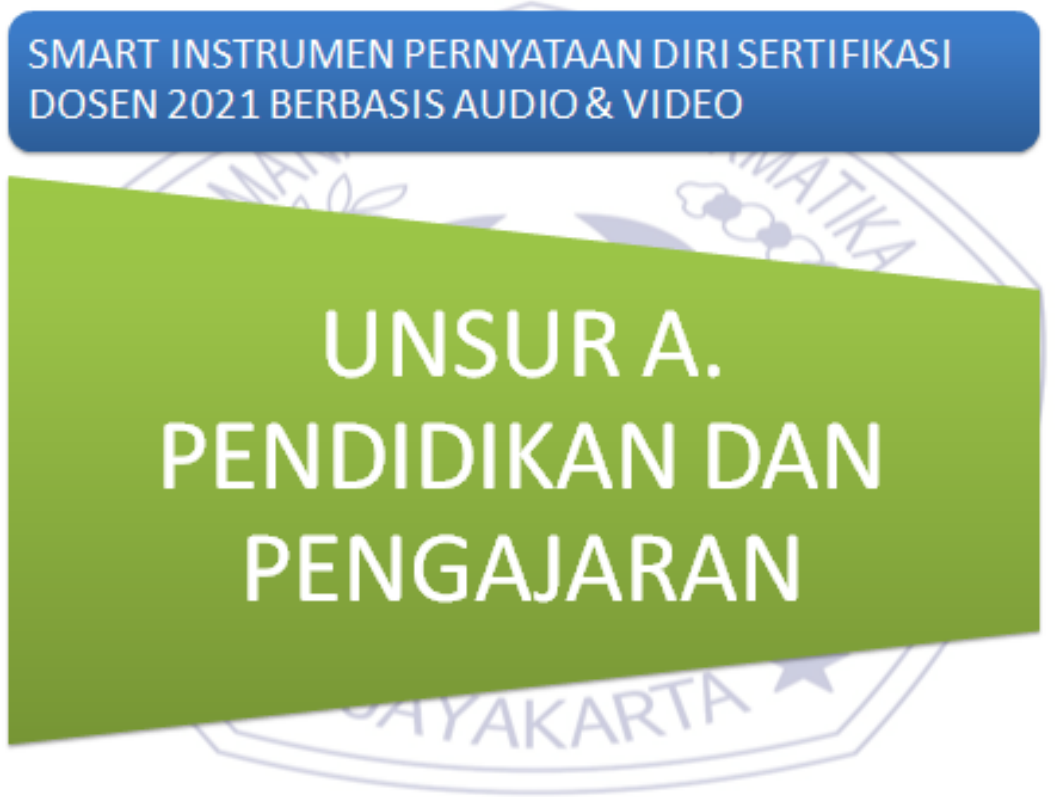

Gambar 4. Unsur A. Pendidikan dan Pengajaran

Pendidkan dan Pengagajaran, dilakasanakan dengan memilki rekaman Audio atau Video sebagai bukti plaksanaan Pendidikan dan Pengajaran baik secara daring maupun tatap muka di ruang kelas konvensional.

Dalam Unsur Pendidikan dan Pengajaran terdiri dari enam butir (6) sebagai berikut: 
TRIDHARMADIMAS: Jurnal Pengabdian Kepada Masyarakat Jayakarta

http://journal.stmikjayakarta.ac.id/index.php/tridharmadimas

EmaiL: info@stmik.jayakarta.ac.id , tridharmadimas.jayakarta@gmail.com

E-ISSN: 2798-8295 (Online), P-ISSN: 2798-8554 (Print) Vol. 1 No.1, Juli 2021 DOI : https://doi.org/10.52362/tridharmadimas.v1i1.501 Halaman 37-55

\section{UNSUR}

A. PENDIDIKAN DAN PENGAJARAN (6 Butir)

\section{VALIDITAS BAHAN KAJIAN \\ DALAM \\ BIDANG KEILMUAN}

2. PENGUASAN TERHADAP

MATERI

3. KESESUAIAN MATERI YANG

DISAMPAIKAN DENGAN CAPAIAN PEMBELAJARAN
4. INTERAKSI DALAM PROSES

\section{PEMBELAJARAN}

5. ASESMEN CAPAIAN

PEMBELAJARAN

6. KREATIVITAS DALAM

MENYAMPAIKAN MATERI

Gambar 5. Unsur Pendidikan dan Pengajaran (6 butir)

This work is licensed under a Creative Commons Attribution-NonCommercial-ShareAlike 4.0 International License. 
TRIDHARMADIMAS: Jurnal Pengabdian Kepada Masyarakat Jayakarta

http://journal.stmikjayakarta.ac.id/index.php/tridharmadimas

EmaiL: info@stmik.jayakarta.ac.id , tridharmadimas.jayakarta@gmail.com

E-ISSN: 2798-8295 (Online), P-ISSN: 2798-8554 (Print) Vol. 1 No.1, Juli 2021 DOI : https://doi.org/10.52362/tridharmadimas.v1i1.501 Halaman 37-55

\section{PENILAIAN UNSUR \\ A. PENDIDIKAN DAN PENGAJARAN (Butir) lanjutan}

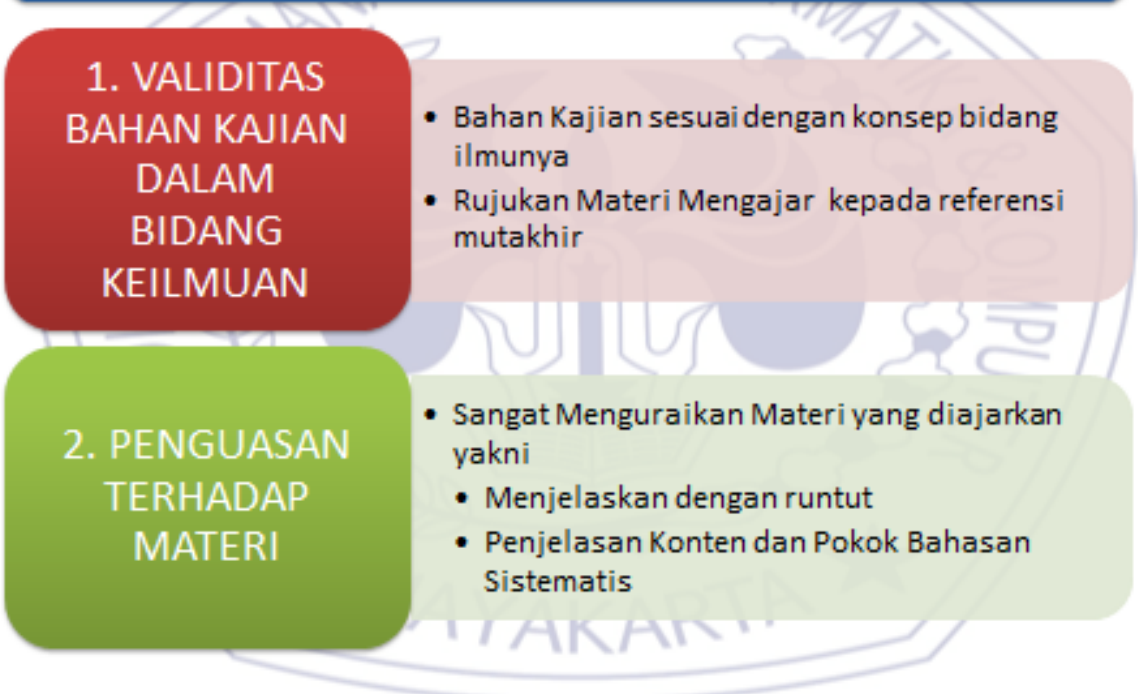

Gambar 6. Penjelasan Butir 1-2 Unsur Pendidkan dan Pengajaran

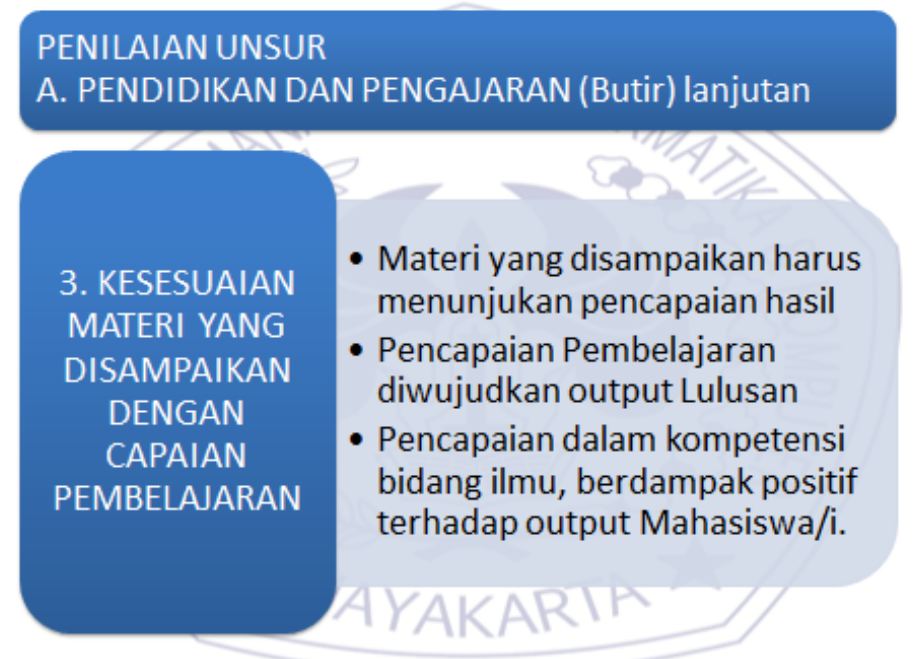

Gambar 7. Penjelasan Butir 3 Unsur Pendidkan dan Pengajaran

This work is licensed under a Creative Commons Attribution-NonCommercial-ShareAlike 4.0 International License. 
TRIDHARMADIMAS: Jurnal Pengabdian Kepada Masyarakat Jayakarta

http://journal.stmikjayakarta.ac.id/index.php/tridharmadimas

EmaiL: info@stmik.jayakarta.ac.id , tridharmadimas.jayakarta@gmail.com

E-ISSN: 2798-8295 (Online), P-ISSN: 2798-8554 (Print) Vol. 1 No.1, Juli 2021 DOI : https://doi.org/10.52362/tridharmadimas.v1i1.501 Halaman 37-55

\section{PENILAIAN UNSUR \\ A. PENDIDIKAN DAN PENGAJARAN (Butir) lanjutan}

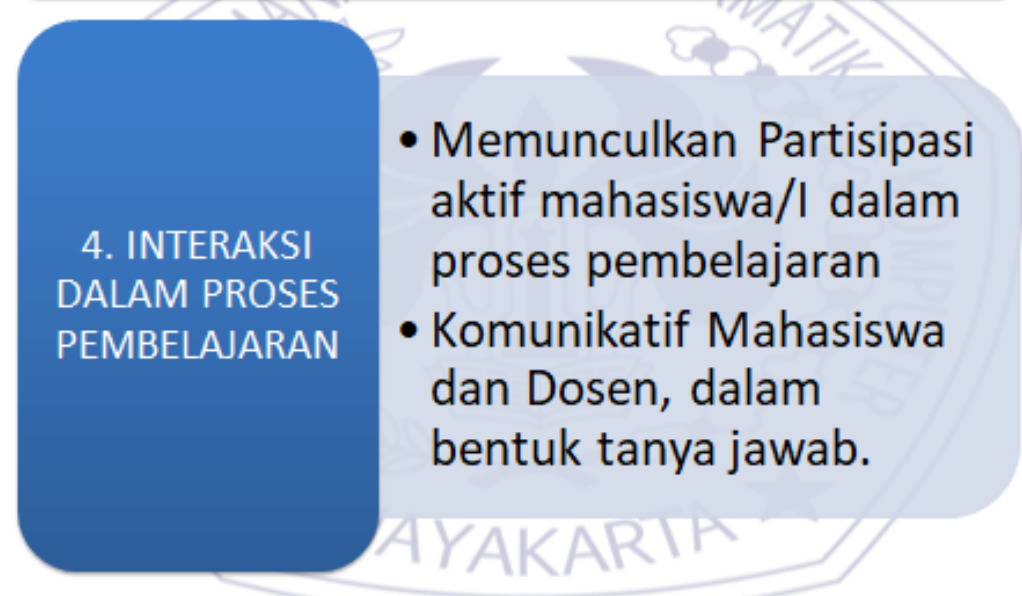

Gambar 8. Penjelasan Butir 4 Unsur Pendidkan dan Pengajaran

\section{PENILAIAN UNSUR \\ A. PENDIDIKAN DAN PENGAJARAN (Butir) lanjutan}

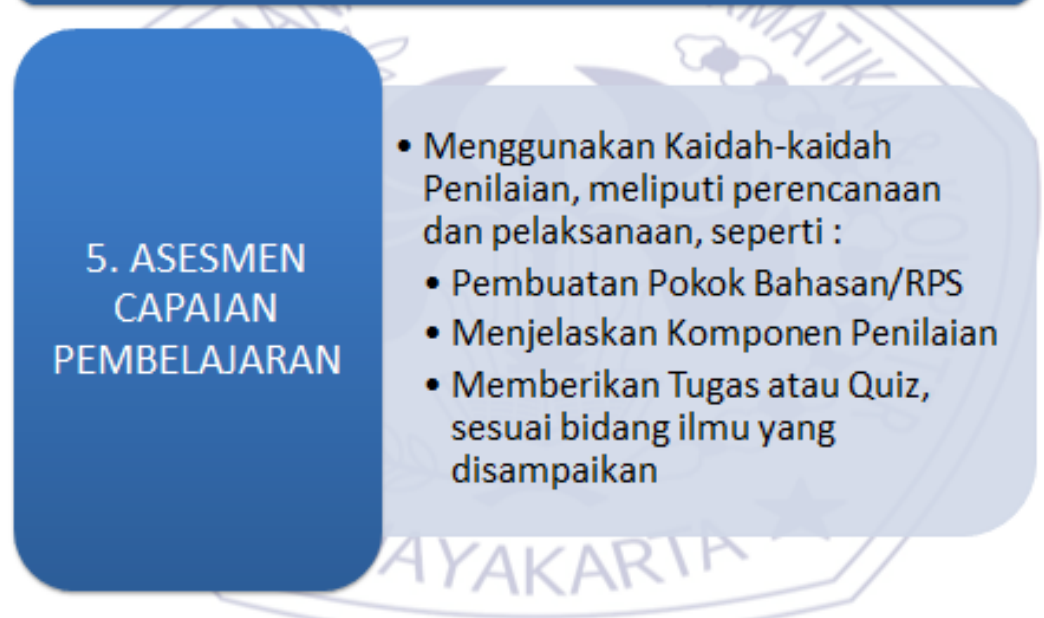

Gambar 9. Penjelasan Butir 5 Unsur Pendidkan dan Pengajaran

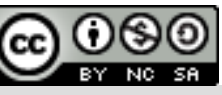

This work is licensed under a Creative Commons Attribution-NonCommercial-ShareAlike 4.0 International License. 
TRIDHARMADIMAS: Jurnal Pengabdian Kepada Masyarakat Jayakarta

http://journal.stmikjayakarta.ac.id/index.php/tridharmadimas

EmaiL: info@stmik.jayakarta.ac.id , tridharmadimas.jayakarta@gmail.com

E-ISSN: 2798-8295 (Online), P-ISSN: 2798-8554 (Print) Vol. 1 No.1, Juli 2021 DOI : https://doi.org/10.52362/tridharmadimas.v1i1.501 Halaman 37-55

\section{PENILAIAN UNSUR \\ A. PENDIDIKAN DAN PENGAJARAN (Butir) lanjutan}

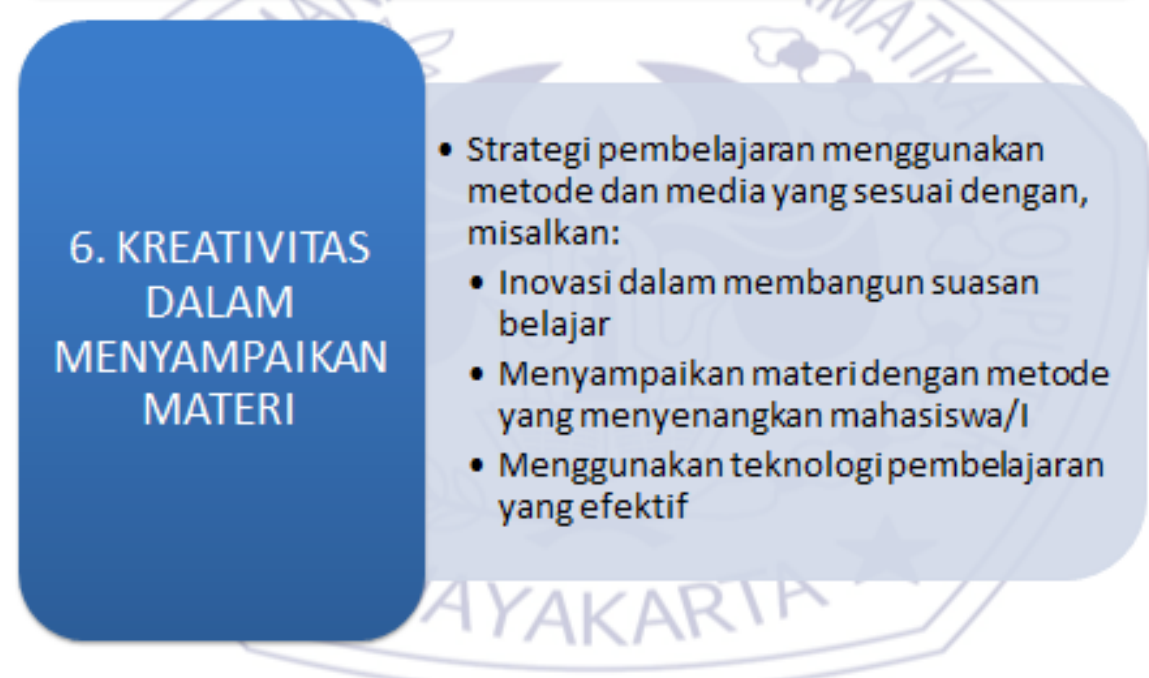

Gambar 10. Penjelasan Butir 6 Unsur Pendidkan dan Pengajaran

B. Unsur B. Penelitian dan Publikasi Karya Ilmiah

SMART INSTRUMEN PERNYATAAN DIRI SERTIFIKASI

DOSEN 2021 BERBASIS AUDIO \& VIDEO

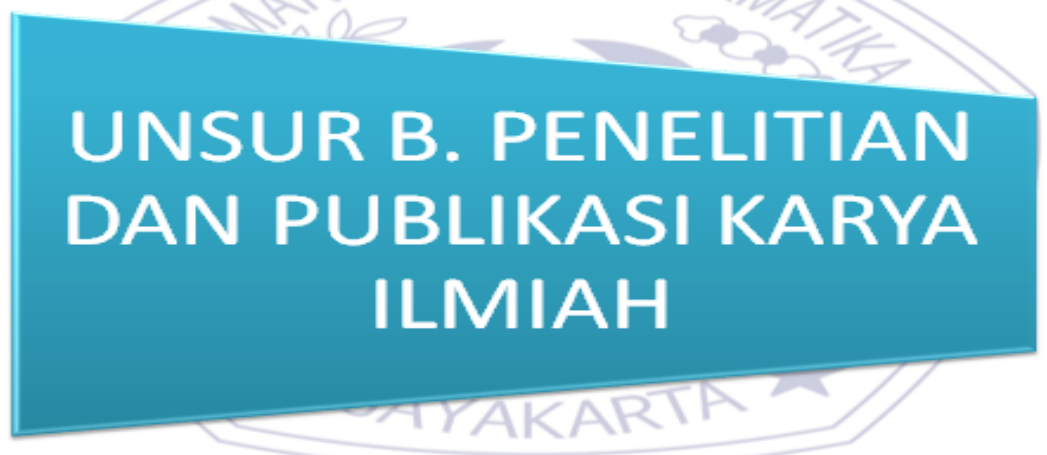

Gambar 11. Unsur B. Penelitian dan Publikasi Karya Ilmiah

This work is licensed under a Creative Commons Attribution-NonCommercial-ShareAlike 4.0 International License. 
TRIDHARMADIMAS: Jurnal Pengabdian Kepada Masyarakat Jayakarta

http://journal.stmikjayakarta.ac.id/index.php/tridharmadimas

EmaiL: info@stmik.jayakarta.ac.id , tridharmadimas.jayakarta@gmail.com

E-ISSN: 2798-8295 (Online), P-ISSN: 2798-8554 (Print) Vol. 1 No.1, Juli 2021 DOI : https://doi.org/10.52362/tridharmadimas.v1i1.501 Halaman 37-55

\section{UNSUR \\ B. PENELITIAN DAN PUBLIKASI KARYA ILMIAH (5 Butir)}

1. MAKNA PENELITIAN YANG DILAKUKAN

2. KESUAIAN DENGAN BIDANG ILMU

3. INOVASI PENELITIAN

4. KATEGORI PUBLIKASI (SINTA, SCOPUS, WOS)

5. KEBERLANJUTAN

Gambar 12. Unsur B. Penelitian dan Publikasi Karya Ilmiah (Ada 5 Butir)

\section{UNSUR}

B. PENELITIAN DAN PUBLIKASI KARYA ILMIAH (Butir) lanjutan

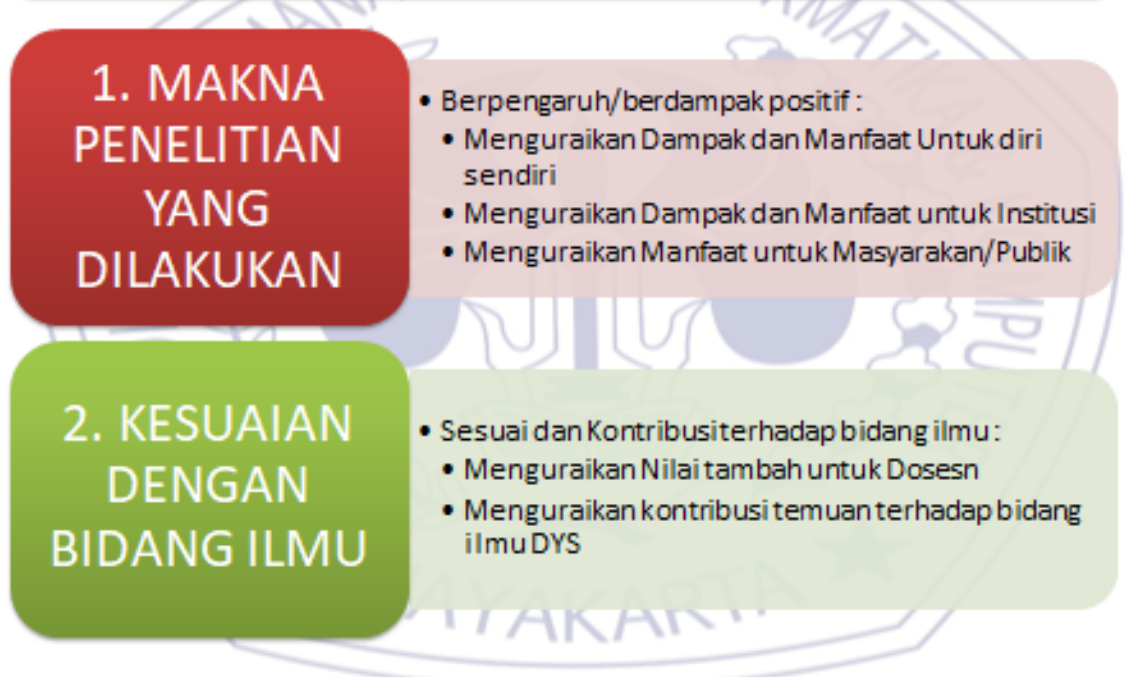

Gambar 13. Butir 1-2 Unsur B. Penelitian dan Publikasi Karya Ilmiah

This work is licensed under a Creative Commons Attribution-NonCommercial-ShareAlike 4.0 International License. 
TRIDHARMADIMAS: Jurnal Pengabdian Kepada Masyarakat Jayakarta

http://journal.stmikjayakarta.ac.id/index.php/tridharmadimas

EmaiL: info@stmik.jayakarta.ac.id , tridharmadimas.jayakarta@gmail.com

E-ISSN: 2798-8295 (Online), P-ISSN: 2798-8554 (Print) Vol. 1 No.1, Juli 2021 DOI : https://doi.org/10.52362/tridharmadimas.v1i1.501 Halaman 37-55

\section{UNSUR}

B. PENELITIAN DAN PUBLIKASI KARYA ILMIAH (Butir) lanjutan

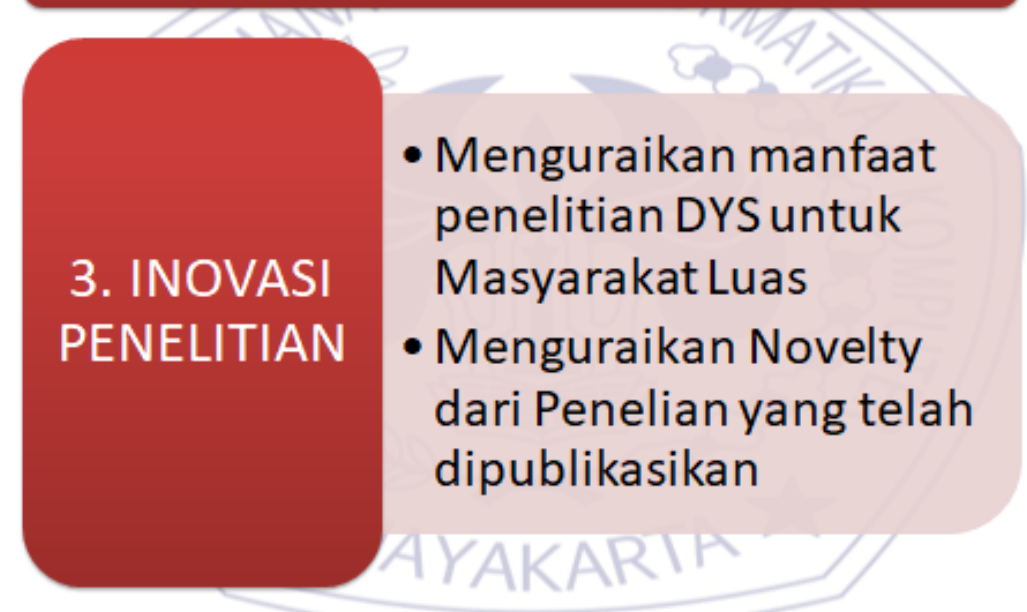

Gambar 14. Butir 3 Unsur B. Penelitian dan Publikasi Karya Ilmiah

\section{UNSUR \\ B. PENELITIAN DAN PUBLIKASI KARYA ILMIAH (Butir) lanjutan}

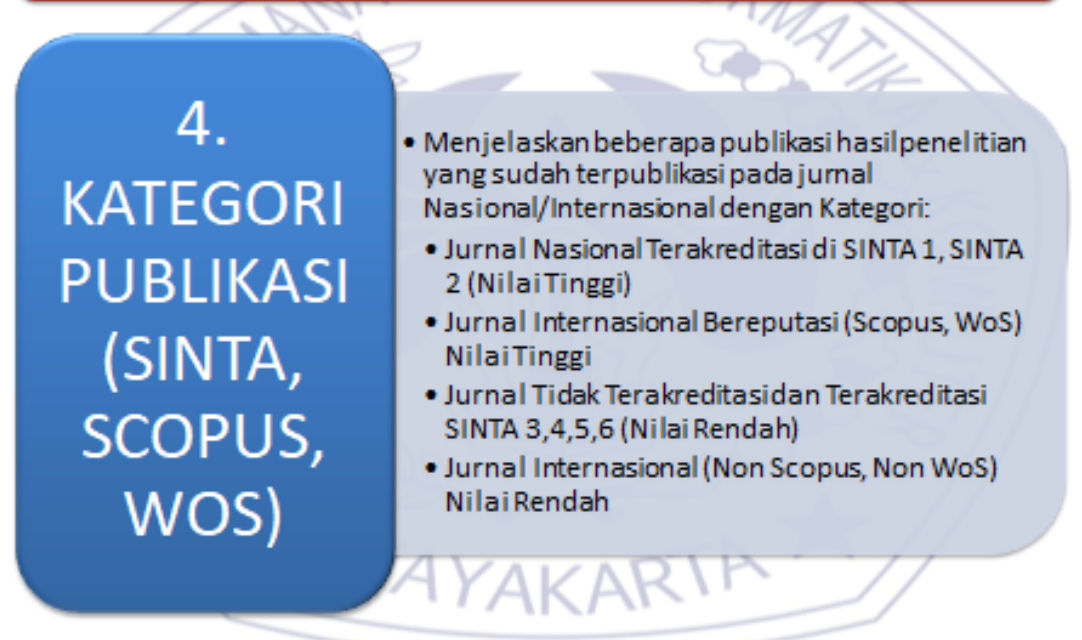

Gambar 15. Butir 4 Unsur B. Penelitian dan Publikasi Karya Ilmiah

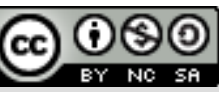

This work is licensed under a Creative Commons Attribution-NonCommercial-ShareAlike 4.0 International License. 
TRIDHARMADIMAS: Jurnal Pengabdian Kepada Masyarakat Jayakarta http://journal.stmikjayakarta.ac.id/index.php/tridharmadimas EmaiL: info@stmik.jayakarta.ac.id , tridharmadimas.jayakarta@gmail.com E-ISSN: 2798-8295 (Online), P-ISSN: 2798-8554 (Print) Vol. 1 No.1, Juli 2021 DOI : https://doi.org/10.52362/tridharmadimas.v1i1.501 Halaman 37-55

\section{UNSUR \\ B. PENELITIAN DAN PUBLIKASI KARYA ILMIAH (Butir) lanjutan}

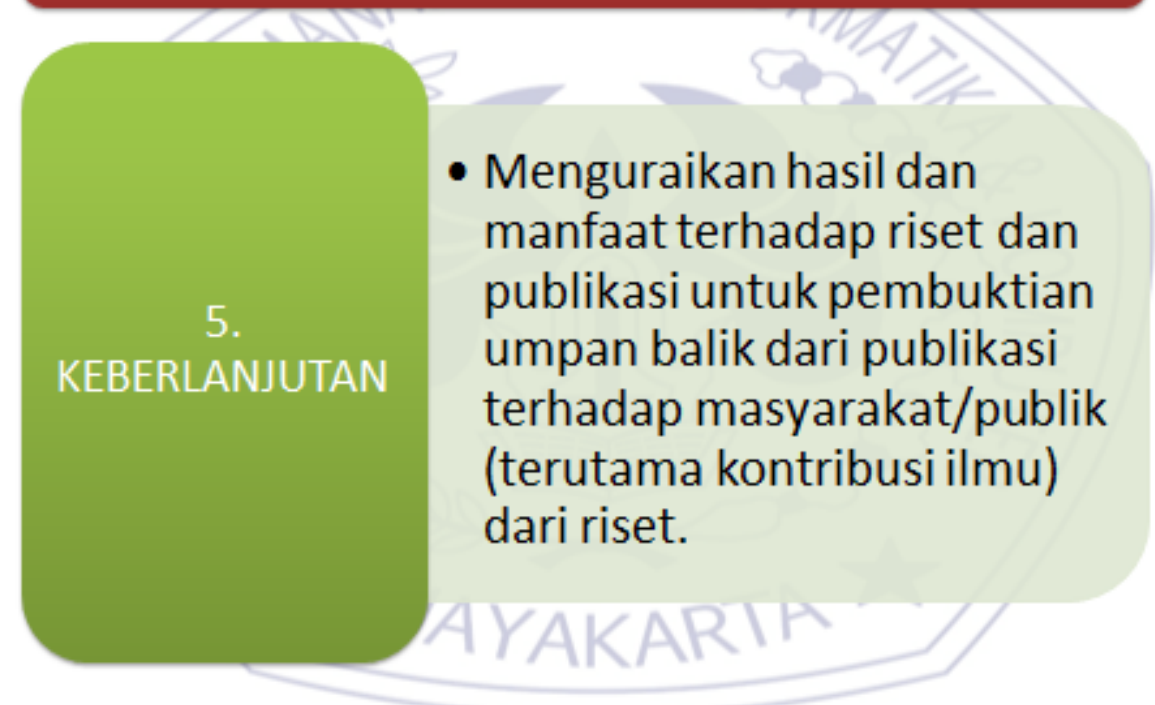

Gambar 16. Butir 5 Unsur B. Penelitian dan Publikasi Karya Ilmiah

C. Unsur C. Pengabdian Kepada Masyarakat

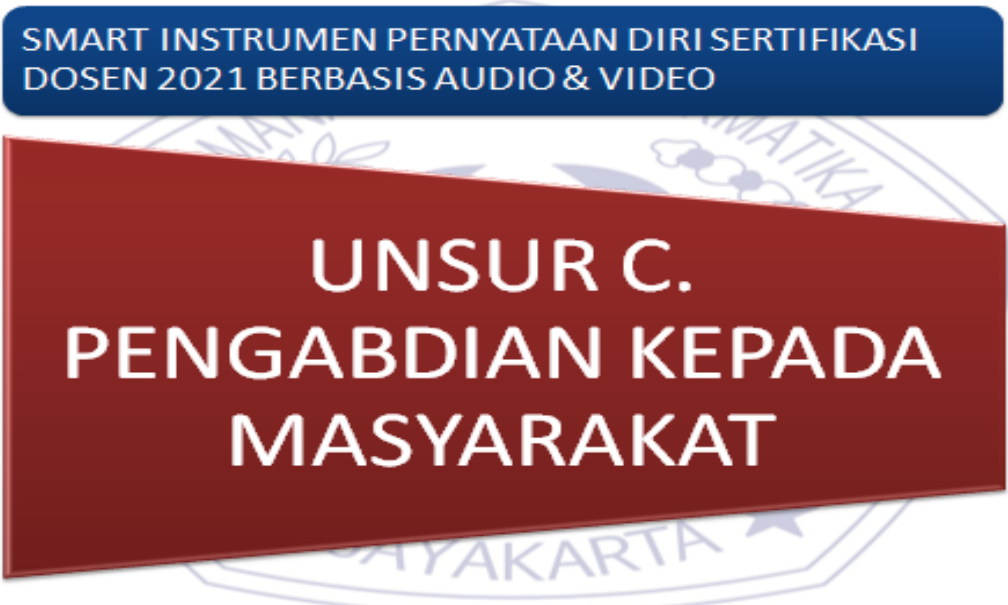

Gambar 17. Unsur C. Pengabdian Kepada Masyarakat

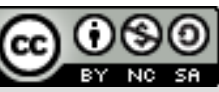

This work is licensed under a Creative Commons Attribution-NonCommercial-ShareAlike 4.0 International License. 
TRIDHARMADIMAS: Jurnal Pengabdian Kepada Masyarakat Jayakarta

http://journal.stmikjayakarta.ac.id/index.php/tridharmadimas

EmaiL: info@stmik.jayakarta.ac.id , tridharmadimas.jayakarta@gmail.com

E-ISSN: 2798-8295 (Online), P-ISSN: 2798-8554 (Print) Vol. 1 No.1, Juli 2021

DOI : https://doi.org/10.52362/tridharmadimas.v1i1.501 Halaman 37-55

\section{UNSUR \\ C. PENGABDIAN KEPADA MASYARAKAT (4 Butir)}

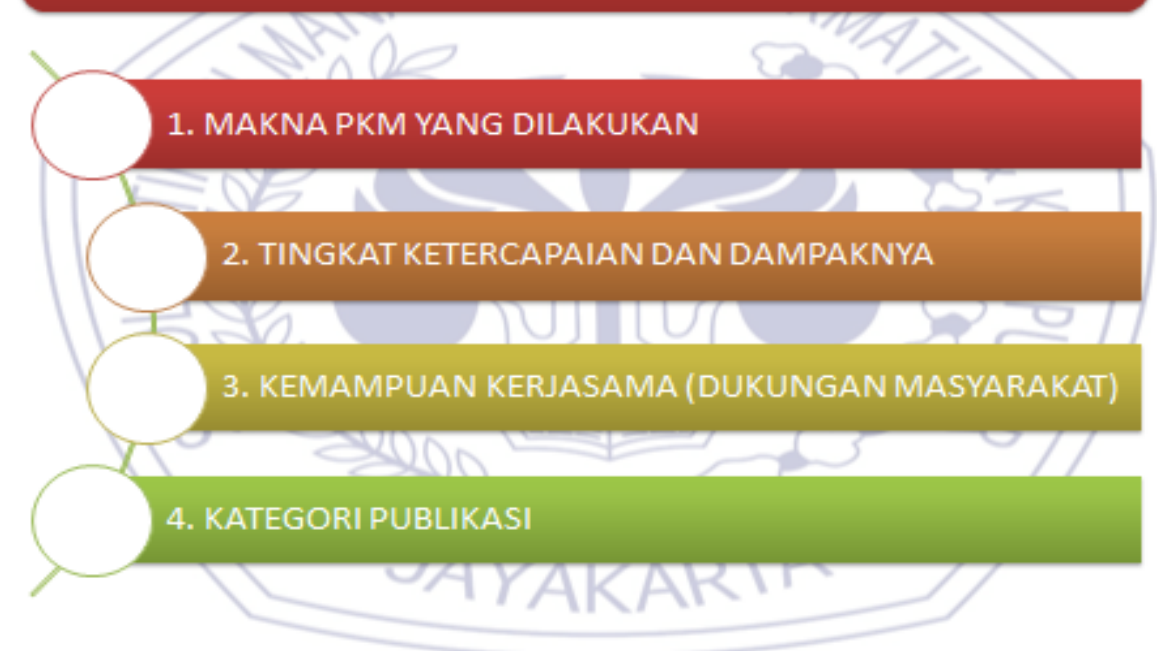

Gambar 18. Unsur C. Pengabdian Kepada Masyarakat ( ada 4 butir)

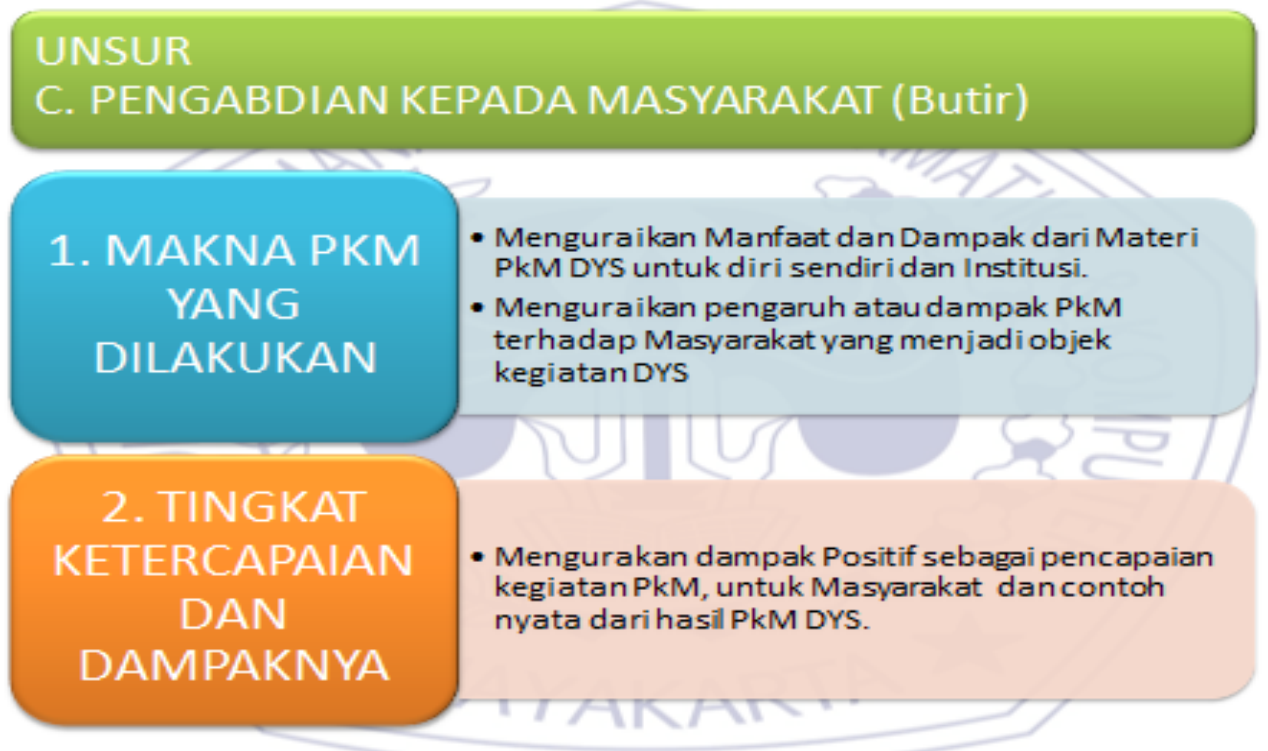

Gambar 18. Butir 1-2 Unsur C. Pengabdian Kepada Masyarakat

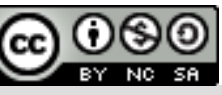

This work is licensed under a Creative Commons Attribution-NonCommercial-ShareAlike 4.0 International License. 
TRIDHARMADIMAS: Jurnal Pengabdian Kepada Masyarakat Jayakarta

http://journal.stmikjayakarta.ac.id/index.php/tridharmadimas

EmaiL: info@stmik.jayakarta.ac.id , tridharmadimas.jayakarta@gmail.com

E-ISSN: 2798-8295 (Online), P-ISSN: 2798-8554 (Print) Vol. 1 No.1, Juli 2021 DOI : https://doi.org/10.52362/tridharmadimas.v1i1.501 Halaman 37-55

\section{UNSUR \\ C. PENGABDIAN KEPADA MASYARAKAT (Butir)}

\section{KEMAMPUAN KERJASAMA (DUKUNGAN MASYARAKAT)}

- Menguraikan bentuk kerjasama institusidengan lembaga objek kegiatan

- Menguraikan dukungan institusi homebase, terhadapkegiatan PkM DYS

4. KATEGORI

- Hasilkegiatan PkM, disarankan untuk menunjukan hasil Publikasi dalam bentuk Jurnal Pengabdian Masyarakat yang terakreditasi SINTA 1,2 (Nilai PUBLIKASI Tinggi) dan Jurnal TerakreditasiSINTA 3,4,5,6 dan Jurnal Tidak Terakreditasi Nilai Rendah.

Gambar 19. Butir 3-4 Unsur C. Pengabdian Kepada Masyarakat

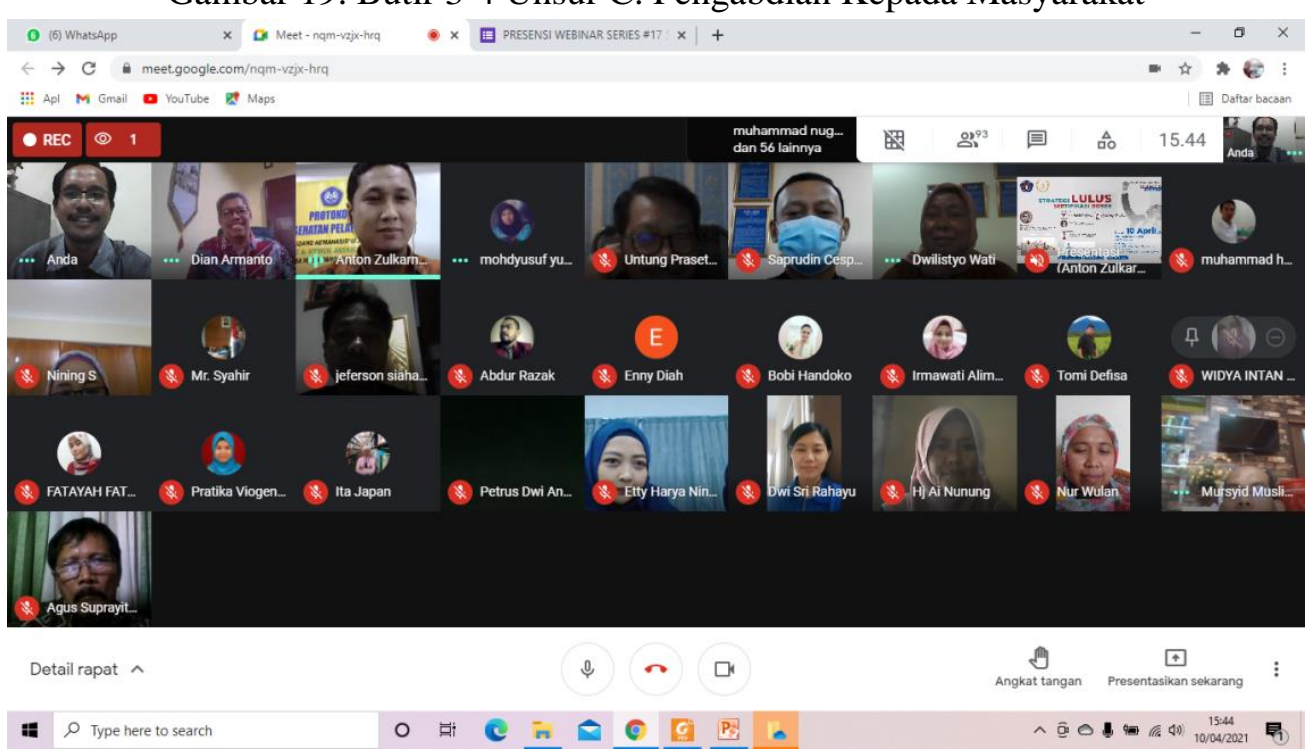

Gambar 20 Pelaksanaan Webinar Seminar Nasional Sebagai Narasumber (Pemateri) Tema:

Strategi Lulus Sertifikasi Dosen, Diselenggarakan oleh STMIK Jayakarta, Sabtu 10 April 2021

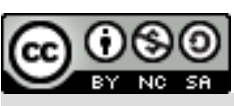

This work is licensed under a Creative Commons Attribution-NonCommercial-ShareAlike 4.0 International License. 
TRIDHARMADIMAS: Jurnal Pengabdian Kepada Masyarakat Jayakarta

http://journal.stmikjayakarta.ac.id/index.php/tridharmadimas

EmaiL: info@stmik.jayakarta.ac.id , tridharmadimas.jayakarta@gmail.com E-ISSN: 2798-8295 (Online), P-ISSN: 2798-8554 (Print) Vol. 1 No.1, Juli 2021 DOI : https://doi.org/10.52362/tridharmadimas.v1i1.501 Halaman 37-55

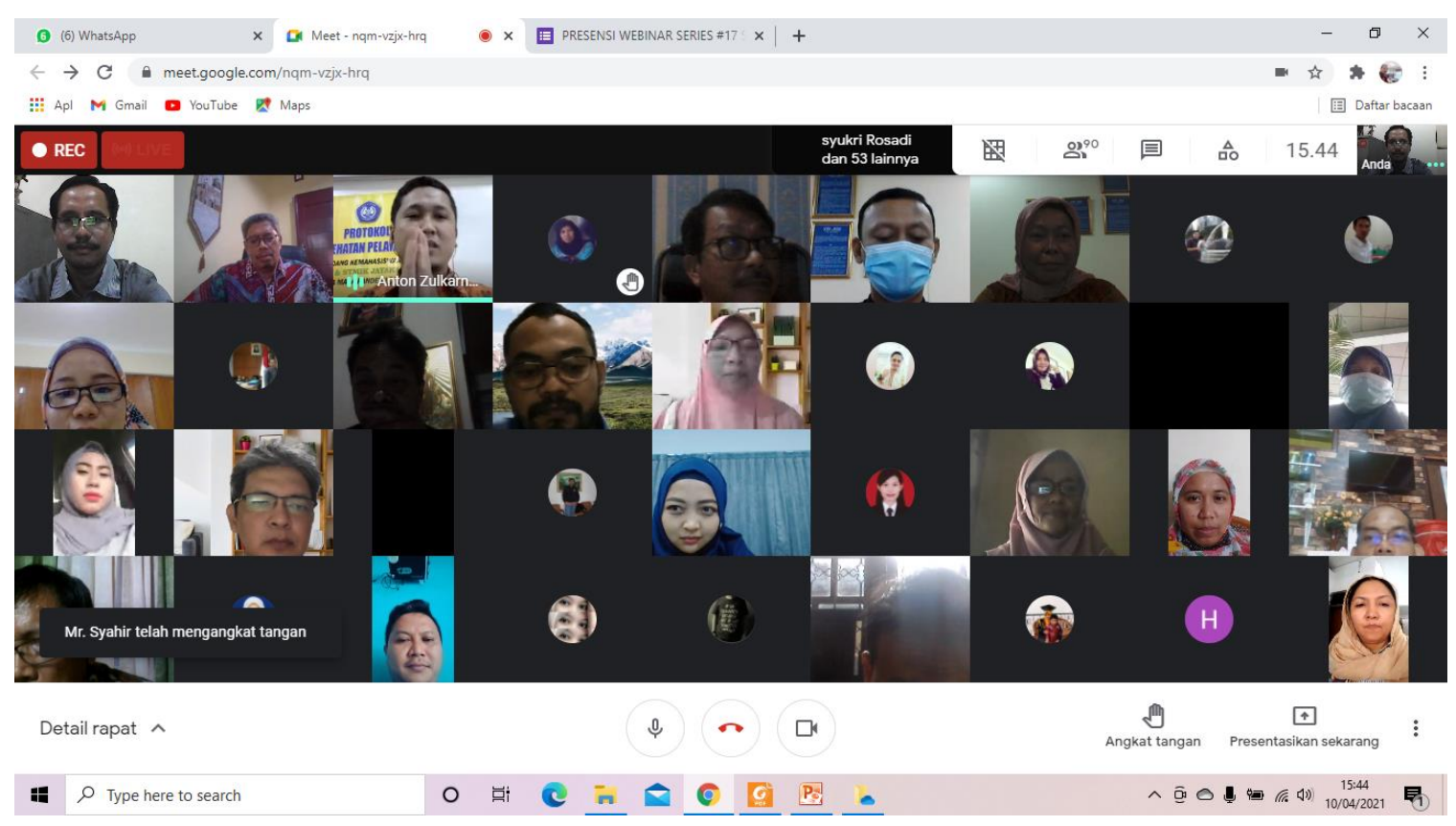

Gambar 21 Pelaksanaan Webinar Seminar Nasional Sebagai Narasumber (Pemateri) Tema: Strategi Lulus Sertifikasi Dosen, Diselenggarakan oleh STMIK Jayakarta, Sabtu 10 April 2021

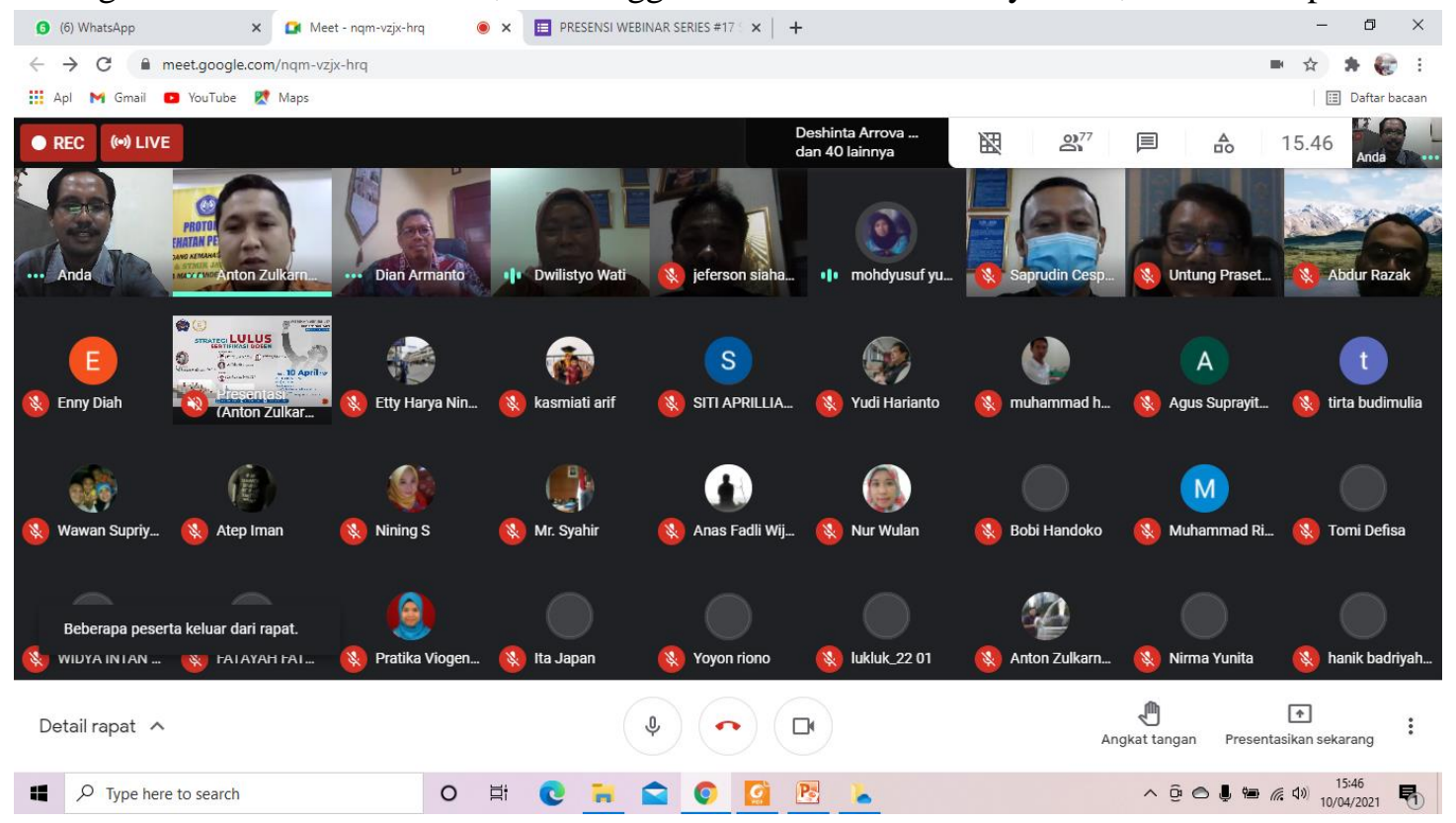

Gambar 22 Pelaksanaan Webinar Seminar Nasional Sebagai Narasumber (Pemateri) Tema:

Strategi Lulus Sertifikasi Dosen, Diselenggarakan oleh STMIK Jayakarta, Sabtu 10 April 2021

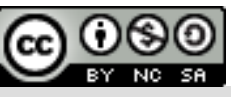

This work is licensed under a Creative Commons Attribution-NonCommercial-ShareAlike 4.0 International License. 
TRIDHARMADIMAS: Jurnal Pengabdian Kepada Masyarakat Jayakarta

http://journal.stmikjayakarta.ac.id/index.php/tridharmadimas

EmaiL: info@stmik.jayakarta.ac.id , tridharmadimas.jayakarta@gmail.com

E-ISSN: 2798-8295 (Online), P-ISSN: 2798-8554 (Print) Vol. 1 No.1, Juli 2021

DOI : https://doi.org/10.52362/tridharmadimas.v1i1.501 Halaman 37-55

\section{KESIMPULAN}

Metode SMART merupak solusi kegiatan belajar dan mengajar, secara daring maupun secara konvensional dalam ruang kelas belajar/perkuliahan. SMART Merupakan Metode yang dapat gunakan untuk melaksanakan Unsur Utama dalam mengikut Sertifikasi Dosen Yakni seorang dosen ; S=Simple, M=Modern-more innovative, $A=$ Accountable, $R=$ Responsive, $T=$ Transparent

\section{REFERENSI}

[1]Paparan Materi Sosialisasi Sertifikasi Dosen (Serdos) Tahun 2021 (TERBARU) Data Dosen Eligible Serdos Tahun 2021 (Kamis, 08/04/2021) Panitia Sertifikasi Pendidik untuk Dosen, Direktorat Sumber Daya, Direktorat Jenderal Pendidikan Tinggi Kementerian Pendidikan dan Kebudayaan

[2]Buku Pedoman sertifikasi pendidik untuk dosen (SERDOS) terintegrasi, Direktorat Jenderal Sumber Daya Ilmu Pengetahuan, Teknologi dan Pendidikan Tinggi Kementerianriset, Teknologi dan Pendidikan Tinggi 2019

[3]Peraturan Pemerintah Republik Indonesia Nomor 37 tahun 2009 tentang Dosen, https://peraturan.bpk.go.id/Home/Details/4956/PP-No-37-Tahun-2009

[4]Verdi Yasin (2021) "Instrumen Sertifikasi Dosen dengan metode SMART Pernyataan diri DYS atau deskripsi diri DYS berbasis audio \& video visual”, Paparan Materi Webinar Seminar Nasional, Tema: Strategi Lulus Sertifikasi Dosen, (Sabtu 10 April) di selenggarakan oleh STMIK Jayakarta, Jakarta-Indonesia.

[5]Undang-Undang Nomor 14 Tahun 2005 tentang Guru dan Dosen menegaskan bahwa guru dan dosenwajib memiliki kualifikasi akademik, kompetensi, sertifikat pendidik, sehat jasmani dan rohani, dan memenuhi kualifikasi lain yang dipersyaratkan satuan pendidikan tinggi tempat bertugas, serta memiliki kemampuan untuk mewujudkan tujuan pendidikan nasional. https://peraturan.bpk.go.id/Home/Details/40266/uu-no-14-tahun-2005

[6]Undang-Undang U Nomor 14 Tahun 2005 tentang Guru dan Dosen, dan Peraturan Pemerintah Republik Indonesia Nomor 37 Tahun 2009 tentang Dosen mengama natkan bahwa dosen adalah pendidik profesional dan ilmuwan dengan tugas utama mentransformasikan, mengembangkan dan menyebarluaskan ilmu pengetahuan, teknologi, dan seni melalui pendidikan, penelitian dan pengabdian kepada masyarakat.

[7]Program sertifikasi dosen merupakan respons terhadap amanat Undang-Undang Republik Indonesia Nomor 14 Tahun 2005 Tentang Guru dan Dosen, sebagaimana dijelaskan pada pasal 1 ayat 2 bahwa "Dosen dinyatakan sebagai pendidik profesional dan ilmuan dengan tugas utama mengajarkan, mengembangkan, dan menyebarluaskan ilmu pengetahuan, teknologi, dan seni melalui pendidikan, penelitian, dan pengabdian kepada masyarakat".

[8]Verdi Yasin (2021) "Rekayasa Perangkat Lunak Berorientasi Objek", Penerbit Mitra Wacana Media, Jakarta-Indonesia.

This work is licensed under a Creative Commons Attribution-NonCommercial-ShareAlike 4.0 International License. 
EmaiL: info@stmik.jayakarta.ac.id , tridharmadimas.jayakarta@gmail.com

E-ISSN: 2798-8295 (Online), P-ISSN: 2798-8554 (Print) Vol. 1 No.1, Juli 2021

DOI : https://doi.org/10.52362/tridharmadimas.v1i1.501 Halaman 37-55

[9] Anggeri S. Nurjaman, Verdi Yasin (2020) “Konsep Desain Aplikasi Sistem Manajemen Kepegawaian Berbasis Web Pada PT. Bintang Komunikasi Utama”, Journal of Information System, Informatics and Computing._E-ISSN: 2597-3673 (Online), P-ISSN: 2579-5201 (Print) Vol. 4 No. 2, December 28, 2020. Pp.143-174.

http://journal.stmikjayakarta.ac.id/index.php/jisicom/article/view/363

[10] Verdi Yasin, Azhar Ahmad Riza, Rumadi Hartawan (2017) "Pengembangan Aplikasi Pemulihan Layanan Bencana Sistem Informasi Peneriman Negara Bukan Pajak Online Di Lingkungan Kementerian Keuangan Republik Indonesia”, Journal of Information System, Informatics and Computing. E-ISSN: 2597-3673 (Online), P-ISSN: 2579-5201 (Print) Vol. 1 No. 1, September 20, 2017. Pp.33-56. http://journal.stmikjayakarta.ac.id/index.php/jisicom/article/view/4

[11] Benni Triyono, Sri Purwanti, Verdi Yasin (2017) "Rekayasa Perangkat Lunak Sistem Informasi Pengiriman Dan Penerimaan Surat Atau Paket Berbasis Web", Journal of Information System, Applied, Management, Accounting and Research, e-ISSN: 2598-8719. p-ISSN: 25988700.Vol.1 No.1 (30 Desember 2017) p46-53 http://journal.stmikjayakarta.ac.id/index.php/jisamar/article/view/12

[12] Julinda Maya Paramudita, Verdi Yasin (2019) "Perancangan Aplikasi Sistem Penyewaan Alat Berat “, Journal of Information System, Applied, Management, Accounting and Research, e-ISSN: 2598-8719. p-ISSN: 2598-8700.Vol.3 No.1 (20 Februari 2019) p23-29 http://journal.stmikjayakarta.ac.id/index.php/jisamar/article/view/73 